\title{
Solar Based Photocatalytic Decolorization of Four Commercial Reactive Dyes Utilizing Bound $\mathrm{TiO}_{2}-\mathrm{Fe}_{3} \mathrm{O}_{4}$ Nanocomposite
}

\author{
Yoanes Maria Vianney ${ }^{1,{ }^{\star}}$, Ivana Rosalyn ${ }^{2}$, and Stephanie Angela ${ }^{2}$ \\ ${ }^{1}$ Department of Biology, Faculty of Biotechnology, University of Surabaya, \\ Jl. Kalirungkut, Surabaya 60292, East Java, Indonesia \\ ${ }^{2}$ Department of Chemical Engineering, Faculty of Engineering, University of Surabaya, \\ J. Kalirungkut, Surabaya 60292, East Java, Indonesia
}

Received August 16, 2017; Accepted February 27, 2018

\begin{abstract}
Dye effluent is one of the most prominent source of water contamination. This study investigated the solar based photocatalytic decolorization of four commercial reactive dyes, which are Reactive Turquoise Blue G 133, Reactive Yellow M4g, Reactive Bordeaux B, and Reactive Red M8b using immobilized $\mathrm{TiO}_{2}-\mathrm{Fe}_{3} \mathrm{O}_{4}$ on three kind of binders as the support, specifically cyanoacrylate glue, oil-based paint, and white Portland cement on PVC plate. $\mathrm{TiO}_{2}-\mathrm{Fe}_{3} \mathrm{O}_{4}$ was synthesized using sol-gel method and placed in muffle furnace at $773 \mathrm{~K}$. The composite of $\mathrm{TiO}_{2}-\mathrm{Fe}_{3} \mathrm{O}_{4}$ was characterized using SEM-EDX and XRD. White cement emerged as the best binder in term of the color removal efficiency of all four dyes compared to other binders, which were more than $90 \%$ color removal after $3 \mathrm{~h}$ of solar irradiation. Moreover, there was significant enhancement on color removal using immobilized photocatalyst on white cement compared to mobile photocatalyst. The kinetic of the decolorization performance followed the pseudo-firstorder reaction. The apparent reaction rate constant was found to decrease along with the increase of the dye concentration. The photodecolorization kinetics fitted the Langmuir-Hinshelwood model. These protocols and results can be applied into textile industrial primary wastewater treatment using solar as a sustainable light and energy source.
\end{abstract}

Keywords: decolorization; reactive dye; solar energy; $\mathrm{TiO}_{2}-\mathrm{Fe}_{3} \mathrm{O}_{4}$ photocatalyst

\section{ABSTRAK}

Limbah pewarna cair merupakan salah satu sumber kontaminasi air yang utama. Penelitian ini menginvestigasi proses dekolorisasi empat pewarna reaktif komersial, yakni Reactive Turquoise Blue G 133, Reactive Yellow M4g, Reactive Bordeaux B, dan Reactive Red M8b berbasis reaksi fotokatalisis $\mathrm{TiO}_{2}-\mathrm{Fe}_{3} \mathrm{O}_{4}$ terimobilisasi oleh tiga pengikat, lem sianoakrilat, cat minyak, dan semen putih, menggunakan cahaya matahari pada plat $\mathrm{PVC}$. $\mathrm{TiO}_{2}-\mathrm{Fe}_{3} \mathrm{O}_{4}$ disintesis dengan metode sol-gel dan dipanaskan di furnace pada suhu $773 \mathrm{~K}$. Setelah itu, komposit $\mathrm{TiO}_{2}-\mathrm{Fe}_{3} \mathrm{O}_{4}$ dikarakterisasi dengan analisis SEM-EDX dan XRD. Hasil menunjukkan bahwa semen putih bertindak sebagai pengikat terbaik yang berhasil memberikan nilai efisiensi dekolorisasi paling tinggi untuk keempat warna, yakni diatas $90 \%$ dekolorisasi setelah 3 jam penyinaran matahari. Bahkan, ada peningkatan efisiensi dekolorisasi yang signifikan untuk fotokatalis yang difiksasi pada semen putih dibanding fotokatalis bebas. Kinetika dekolorisasi mengikuti reaksi orde pseudo satu. Nilai konstanta laju reaksi semu didapatkan menurun seiring kenaikan konsentrasi pewarna yang diujikan. Kinetika fotodekolorisasi sesuai dengan mode Langmuir-Hinshelwood. Protokol dan hasil didapat mampu diaplikasikan untuk pengelolaan limbah cair primer industri tekstil dengan menggunakan matahari sebagai sumber cahaya dan energi terbarukan.

Kata Kunci: dekolorisasi; energi matahari; fotokatalis $\mathrm{TiO}_{2}-\mathrm{Fe}_{3} \mathrm{O}_{4}$; pewarna reaktif

\section{INTRODUCTION}

Textile and dyestuff industries have been growing fast in accordance to the population growth. The world market of dyestuff is currently around 1.3 million tons. Organic dyes contain kinds of dyes, but $50 \%$ of them are synthetic azo dyes [1]. Reactive synthetic dye has become popular, in an average of $50 \%$ market share [2].
This dye has bright colors and ease of washing due to its unique reactive groups that covalently bond to the cellulose fiber which is not occurred in the natural dye. Thus, it is preferable to the global market. The chromophoric groups of reactive dyes are azo, anthraquinone, phthalocyanine, and triarylmethane, etc. [3-4]. Some dyes contain two or more functional groups, such as dichlorotriazine and sulphatoethylsulphone

* Corresponding author. Tel : +62-821-4434-5502

DOI: $10.22146 /$ ijc. 27549

Email address : yoanes_mv@yahoo.co.id 
(vinyl sulphone) substituents [5]. Utilization of these reactive dyes has led to a major source of water contamination [6]. Textile industries produce many types of wastewater effluent, including the huge amount of colored dye waste effluent [7]. Reactive waste reached 5 to $1500 \mathrm{mg} \cdot \mathrm{L}^{-1}$ in effluent. Some aromatic dyes exhibit carcinogenic effect even before degraded. However, the main causes of carcinogenicity are the aromatic amines, for instance, benzidine. Benzidine is the reduction product of azo dyes [8-9]. Azo dyes were intended to be recalcitrant for long term use [10]. These dyes cannot be easily degraded by aerobic sewage treatment due to their large degree of aromatics and many substitute groups contributing to the stability of the dye [11-12]. Commercial azo-dyes have more than $2000 \mathrm{~h}$ for the half lives in sunlight [13].

Some techniques of decolorization, such as flocculation, separation (reverse osmosis, ultrafiltration), and adsorption on activated carbon or resin can be done [1]. However, these techniques only transfer the compounds from water to other phase without destruction, therefore generate secondary pollution [1315]. A lot of researches has concluded that these dyes can be degraded by advanced oxidation processes (AOPs) [15-17]. These decolorization and degradation processes are based on Fenton and photo-Fenton reaction, which have wide applications, high availability, ease of handling, low fund, and a high generation of hydroxyl radicals that can oxidize many contaminants [15]. Homogenous catalyst for Fenton reaction creates another problem in water treatment such as low regeneration of the metal salt of the catalyst, lead to a huge usage of metal salts, limited $\mathrm{pH}$ range, and high $\mathrm{H}_{2} \mathrm{O}_{2}$ consumption [17-18]. Hence, the usage of heterogeneous photocatalyst in terms of decolorization and degradation of dye technology appears to attract much interest [19].

Photocatalyst is unvarying semiconductors that promote reaction in the presence of light. Among many semiconductors, $\mathrm{TiO}_{2}$ was chosen generally due its high availability, non-toxic property, strong oxidizing power, stability in aqueous solution, and long term photostability [1]. Its anatase form is a superior in term of photocatalytic activity compared to rutile, due to its larger indirect band gap $(3.2 \mathrm{eV})$ related to UV wavelength of $385 \mathrm{~nm}$ as the excitation wave length and higher surface adsorption capacity of hydroxyl groups [20-21]. In most report, UV light irradiator was used for the purpose of decolorization which needs energy. The use of solar as source of energy has been increasing [12,22-25]. Solar as natural and abundant light source can be a substitute to artificial light source such as UV/Vis lamp. One of the limitation of pure $\mathrm{TiO}_{2}$ is the quick recombination process of its electrons which are generated by photon energy [22]. One method to enhance the photocatalytic activity is addition of dopant such as transition metal oxide [26]. $\mathrm{Fe}_{3} \mathrm{O}_{4}$ could be used to enhance the photoactivity of $\mathrm{TiO}_{2}$, exert a good sorption capability, and retain magnetic properties to reuse the photocatalyst $[9,27-28]$. $\mathrm{Fe}_{3} \mathrm{O}_{4}$ has narrow indirect band gap $(2.87 \mathrm{eV})$ than $\mathrm{TiO}_{2}$ [29]. The purpose of these dopants is to narrow the band gap of the photocatalyst and make it closer the solar spectrum [26].

Many studies have reported $\mathrm{TiO}_{2}$ photocatalyst immobilization on various binders such as concrete blocks [14], glass plate [30], paper [13], sand [31], ceramic [32], and activated carbon [33]. Some binders such as cement [14,30], white cement [34], and cyanoacrylate adhesive [35] have the ability to immobilize photocatalyst on their surface. Deposition of photocatalyst on several supports were used to reduce the risk of losing the photocatalyst due to mixing, washing or scratch [14]. Moreover, Khatee et al. [34] reported that there was enhancement of decolorization of Alphazurine $\mathrm{FG}$ due to the addition of $\mathrm{TiO}_{2}$ nanomaterials to Portland cement.

Few studies compared the effect of binders used to immobilize photocatalyst on decolorization performance. The aim of this study was to investigate the usage of three binders, specifically cyanoacrylate glue, oil-based paint, and white cement related to the photocatalytic decolorization efficiency under solar irradiation, in order to immobilize the photocatalyst material. This study was also designed to find the best binder for decolorization process. Four commercial reactive dyes were used in this study, namely Reactive Yellow M4g (Yellow 22), Reactive Red M8b (Red 11), Reactive Turquoise Blue G 133 (Blue 21), and Reactive Bordeaux B (Red 49). Kinetic studies of decolorization of each dyes with different initial concentrations based on fitted pseudo-first-order reaction and adapted to Langmuir-Hinshelwood equation were also provided in this paper.

\section{EXPERIMENTAL SECTION}

\section{Materials}

$\mathrm{TiO}_{2}$ anatase (KA-100), $\mathrm{FeSO}_{4} .7 \mathrm{H}_{2} \mathrm{O}$ (Merck), $\mathrm{FeCl}_{3} 6 \mathrm{H}_{2} \mathrm{O}$ (Merck), $\mathrm{HCl}$ (SAP Chemicals), and $\mathrm{NaOH}$ (Merck) were used. Some binders were used in this study, namely cyanoacrylate glue (Tong Shen Enterprise Co., Ltd.), oil-based paint (Avian), and white Portland cement (Indocement). The commercial dyes used in this study were Reactive Yellow M4g (Yellow 22), Reactive Red M8b (Red 11), Reactive Turquoise Blue G 133 (Blue 21), and Reactive Bordeaux B (Red 49). All dyes were technical grade and purchased from Indonesian textile industry in Pekalongan City, Central Java, Indonesia. Characteristics and specifications of the dyes can be seen in Table 1. Standard curve of each 
Table 1. Commercial dyes description

\begin{tabular}{cccccc}
\hline No & Name & Classification & Molecular formulas & $\begin{array}{c}\text { Molecular weight } \\
\left(\mathrm{g} \cdot \mathrm{mol}^{-1}\right)\end{array}$ & $\begin{array}{c}\lambda_{\max } \\
(\mathrm{nm})\end{array}$ \\
\hline 1 & Reactive Yellow M4g & Dichlortriazine & $\mathrm{C}_{19} \mathrm{H}_{12} \mathrm{Cl}_{2} \mathrm{~N}_{8} \mathrm{O}_{9} \mathrm{~S}_{2}$ & 631.37848 & 409 \\
2 & Reactive Red M8b & Dichlortriazine & $\mathrm{C}_{20} \mathrm{H}_{9} \mathrm{Cl}_{2} \mathrm{~N}_{6} \mathrm{Na}_{3} \mathrm{O}_{9} \mathrm{~S}_{2}$ & 681.33 & 544 \\
3 & Reactive Turquoise Blue G 133 & Vinyl Sulphone & $\mathrm{C}_{40} \mathrm{H}_{25} \mathrm{CuN}_{9} \mathrm{O}_{14} \mathrm{~S}_{5}$ & 1079.535 & 624 \\
4 & Reactive Bordeaux B & Vinyl Sulphone & $\mathrm{C}_{18} \mathrm{H}_{14} \mathrm{~N}_{2} \mathrm{Na}_{2} \mathrm{O}_{11} \mathrm{~S}_{3}$ & 576.49 & 508 \\
\hline
\end{tabular}

Table 2. Standard curve of four commercial dyes

\begin{tabular}{ccccc}
\hline No & Name & Standard Curve & $\mathrm{r}^{2}$ & $\begin{array}{c}\text { Range of Concentration } \\
\left(\mathrm{mg} \cdot \mathrm{L}^{-1}\right)\end{array}$ \\
\hline 1 & Reactive Yellow M4g & $\mathrm{Y}=0.071 \mathrm{X}+0.015$ & 0.9985 & $5-500$ \\
2 & Reactive Red M8b & $\mathrm{Y}=0.0145 \mathrm{X}+0.0231$ & 0.9971 & $4-250$ \\
3 & Reactive Turquoise Blue G 133 & $\mathrm{Y}=0.014 \mathrm{X}-0.0258$ & 0.9985 & $5-250$ \\
4 & Reactive Bordeaux B & $\mathrm{Y}=0.032 \mathrm{X}-0.001$ & 0.9996 & $1-100$ \\
\hline a Y axis was Absorbance at the maximum wavelength of the respective dyes while X was the concentration of each dye particularly
\end{tabular}

dye was described in Table 2. The distilled water was used in all the experiments.

\section{Instrumentation}

Magnetic stirrer (Fisher Scientific), oven (Binder FD 115), $\mathrm{pH}$ meter (Eutech $\mathrm{pH} 700$ ) and muffle furnace (Thermo Scientific Thermolyne ${ }^{\mathrm{TM}}$ ) were used for the preparation process of photocatalyst. Scanning Electron Microscopy- Energy-dispersive X-ray Spectroscopy (SEM-EDS) utilizing EVO MA 10 Scanning Electron Microscope (Zeiss) with EDS detector (Bruker) and X-Ray Difraction (XRD) analysis using X'pert X-ray diffractometer (PANalytical PW 3373/00) were employed to examine the synthezised photocatalyst. Centrifuge (Hettich ${ }^{\circledR}$ Universal 320R), UV-Vis spectrophotometer (Genesys ${ }^{\mathrm{TM}} 10 \mathrm{~S}$ ), and Lux meter (Sanwa LX2) were used to study the photocatalyst performance. Other instrument was Ohaus $^{\circledR}$ PA214 Pioneer ${ }^{\mathrm{TM}}$ analytical balance (Ohaus).

\section{Procedure}

\section{Preparation of $\mathrm{TiO}_{2}-\mathrm{Fe}_{3} \mathrm{O}_{4}$ nanocomposite}

The method to synthesize photocatalyst was adopted from Chen et al. [9] using acid sol-gel method. 10 g FeSO $4.7 \mathrm{H}_{2} \mathrm{O}$ and $5 \mathrm{~g} \mathrm{FeCl}_{3} .6 \mathrm{H}_{2} \mathrm{O}$ was added to $200 \mathrm{~mL}$ of distilled water. $\mathrm{pH}$ of the mixture was adjusted to 11 by using $\mathrm{NaOH}$ solution $(1 \mathrm{M})$ and the mixture was continuously stirred for $1 \mathrm{~h}$. The mixture was filtered using Buchner funnel and then aged in oven at $343 \mathrm{~K}$ for $4 \mathrm{~h}$. The black particles were washed with distilled water until neutral and dried in oven. $\mathrm{Fe}_{3} \mathrm{O}_{4}$ crystals $(8.5 \mathrm{~g})$ was suspended in $150 \mathrm{~mL}$ of distilled water. The mixture was sonicated for $20 \mathrm{~min}$.

$\mathrm{TiO}_{2}$ powder $(1.5 \mathrm{~g})$ was suspended in $100 \mathrm{~mL}$ of distilled water and then sonicated for $20 \mathrm{~min}$. The mixture was dispersed by adding $\mathrm{HCl}(1 \mathrm{M})$ until $\mathrm{pH}$ reach 1.5 with strong stirring [14]. This mixture was then mixed with
$\mathrm{Fe}_{3} \mathrm{O}_{4}$ mixture that had been sonicated and subjected to a vigorous stirring for $30 \mathrm{~min}$ and then left to stand for 24 h. The $\mathrm{TiO}_{2}-\mathrm{Fe}_{3} \mathrm{O}_{4}$ mixture was filtered and dried in oven at $353 \mathrm{~K}$ followed by aging process in muffle furnace at $773 \mathrm{~K}$ for $3 \mathrm{~h}$ to obtain $\mathrm{TiO}_{2}-\mathrm{Fe}_{3} \mathrm{O}_{4}$ nanocomposite.

\section{Characterization of photocatalyst}

The crystal surface morphology and elemental analysis was examined using SEM-EDS analysis. XRD patterns of the samples were obtained with the range of angle 5-90 (20) (CuKa, $\lambda=1.5406)$. Average crystallite size was counted using Debye-Scherrer's formula:

$\mathrm{D}=\frac{\mathrm{K} \lambda}{\beta \cos \theta}$

where $D=$ crystallite size $(\mathrm{nm}), \mathrm{K}=0.94, \lambda(\mathrm{CuK \alpha})=$ $0.15406 \mathrm{~nm}, \beta=$ full-width at half maximum of the major peaks (rad).

\section{Photocatalytic performance experiment}

Evaluation of binder on decolorization of four reactive dyes. $\mathrm{TiO}_{2}-\mathrm{Fe}_{3} \mathrm{O}_{4}$ photocatalyst were mixed thoroughly with respective binder, namely oil-based paint, white Portland cement, and cyanoacrylate glue with 1:3 ratio with a suitable amount of distilled water. The binders were applied into the inner surface of the polyvinyl chloride (PVC) plates with a diameter of $10 \mathrm{~cm}$ and $5 \mathrm{~cm}$ of height. The binders were $1 \mathrm{~mm}$ thickness and $7 \mathrm{~mm}$ in height. It was allowed to dry for $24 \mathrm{~h}$ at room temperature. The amount of deposited photocatalyst on the plates was $1 \mathrm{~g}$, hence, the specific amount of each plate was $24.39 \mathrm{mg} \cdot \mathrm{cm}^{-2}$.

Dye solution $(50 \mathrm{~mL}$, Turquoise Blue $\mathrm{G} 133=$ $210.9143 \mathrm{mg} \cdot \mathrm{L}^{-1}$, Yellow $\mathrm{M} 4 \mathrm{~g}=127.6056 \mathrm{mg} \cdot \mathrm{L}^{-1}$, Bordeaux $\mathrm{B}=113.3125 \mathrm{mg} \cdot \mathrm{L}^{-1}$, and Red $\mathrm{M} 8 \mathrm{~b}=$ $140,7517 \mathrm{mg} \cdot \mathrm{L}^{-1}$ ) was poured on the plates. The solutions were irradiated with sun from 11:00 A.M. until 02:00 P.M. in Surabaya, Indonesia. The aqueous solution was aerated during the experiment to keep it homogenous. The intensities of the light were measured 
with lux meter each hour and shown in Table 3. A certain amount of distilled water was added into the plate to avoid reduce in volume due to evaporation. The $\mathrm{pH}$ of the experiment was kept at 6.8. Each color was poured on different plate with two replications. Controls were made by employing plate without photocatalyst and binder, plate with only $1 \mathrm{~g}$ of photocatalyst, and plate with binder. All samples were centrifuged at $10.000 \mathrm{~g}, 5 \mathrm{~min}, 4^{\circ} \mathrm{C}$. The concentration of the solution was measured spectrophotometrically with the respective $\lambda_{\max }$ (Table 1) and the absorbance was correlated with the concentration using standard curve shown in Table 2. The color removal efficiencies of each treatment are given by:

$\%$ color removal efficiency $=100 \% \times \frac{\left(\mathrm{C}_{0}-\mathrm{C}\right)}{\mathrm{C}_{0}}$

where $C_{0}$ is the initial concentration of the dye, and $C$ is the mean of two sample concentrations after experiment. The data within the same dye were analysed using oneway ANOVA and continued with multiple comparison analysis using Tukey's Honestly Significance Difference (HSD) with 95\% confidence interval. Statistical measurement was done by using Minitab 17 (Minitab Inc., Pennsylvania, United States).

Effect of concentration and kinetic studies. The best binder obtained by the previous experiment was used to measure the kinetics and to examine the effect of dye concentration to the photocatalytic performance. $50 \mathrm{~mL}$ of dye solutions with different concentration were poured into the plates. The concentrations used in this experiment were mentioned in Table 4. The solutions were irradiated with sun from 11:00 A.M. until 03:00 P.M. in Surabaya, Indonesia and were mixed during the experiment to keep it homogenous. A certain amount of distilled water was added into the plate to avoid decrement in volume due to evaporation. The $\mathrm{pH}$ of the experiment was kept at $6.8 .1 \mathrm{~mL}$ of aliquots were taken at $30 \mathrm{~min}$ intervals and analyzed spectrophotometrically for dye decolorization.

The determination of approximate reaction rate constant of each concentration in each dye was determined by simplifying the Langmuir-Hinshelwood kinetics model. Many experiments reported that the photocatalytic decolorization fitted the LangmuirHinshelwood model [13,15,36-38].
$\mathrm{r}=\frac{\mathrm{dC}}{\mathrm{dt}}=\frac{\mathrm{kKC}}{1+\mathrm{KC}}$

where $r$ is the oxidation rate of reactant $\left(\mathrm{mg} \cdot \mathrm{L}^{-1} \cdot \mathrm{min}^{-1}\right), \mathrm{C}$ is the concentration of the dye $\left(\mathrm{mg}^{-\mathrm{L}^{-1}}\right)$, $\mathrm{t}$ is the irradiation time, $\mathrm{K}$ is the reaction rate constant $\left(\mathrm{mg} \cdot \mathrm{L}^{-1} \cdot \mathrm{min}^{-1}\right)$ and $\mathrm{K}$ represents the adsorption equilibrium constant $\left(\mathrm{L} \cdot \mathrm{mg}^{-1}\right)$. Due to millimolar concentration of the dye is considered small $[15,39]$, the model can be simplified to a pseudofirst-order equation

$$
\begin{aligned}
& -\frac{d C}{d t}=k^{\prime} C_{0} \\
& \ln \left(\frac{C}{C_{0}}\right)=-k^{\prime} t
\end{aligned}
$$

where $C$ is the concentration of the sample $\left(\mathrm{mg} \cdot \mathrm{L}^{-1}\right), \mathrm{C}_{0}$ is the initial concentration of sample $\left(\mathrm{mg}^{-\mathrm{L}^{-1}}\right)$, $\mathrm{t}$ represents irradiation time (min), and $k^{\prime}$ represents apparent first-order rate constant $\left(\mathrm{min}^{-1}\right)$. The apparent rate constants were determined by using linear regression. First-order kinetics suited for this study [13,15,36-38,40-42]. By plotting linear regression of initial concentration versus $k^{\prime}$ [43-44], the value of $k$ and $K$ from the Langmuir-Hinshelwood model can be determined with the following equation:

$\frac{1}{\mathrm{~K}^{\prime}}=\frac{1}{\mathrm{Kk}}+\frac{\mathrm{C}_{0}}{\mathrm{k}}$

All graphs were plotted using Microsoft Excel 2016 (Microsoft Corp., Washington, United States)

\section{RESULT AND DISCUSSION}

\section{SEM and XRD analysis of $\mathrm{TiO}_{2}-\mathrm{Fe}_{3} \mathrm{O}_{4}$ Photocatalyst}

SEM image of the photocatalyst is shown in Fig. 1(a). The morphologies of the agglomerates are spherical and uniform sizes for about 100-400 nm. Fig. 1 (b) shows the spectrum of the EDS analysis. The

Table 3. Solar light intensity

\begin{tabular}{ccc}
\hline No & Time & Solar light intensity $\left(\mathrm{Im} \mathrm{m}^{-2}\right)$ \\
\hline 1 & $11: 00$ A.M. & 81000 \\
2 & $12: 00$ A.M. & 107000 \\
3 & $1: 00$ P.M. & 115000 \\
4 & $2: 00$ P.M. & 103000 \\
5 & $3: 00$ P.M. & 89000 \\
\hline
\end{tabular}

Table 4. Concentration of the dye used in the degradation kinetic experiments

\begin{tabular}{ccccc}
\hline No & \multicolumn{4}{c}{ Initial Concentration $\left(\mathrm{mg} \cdot \mathrm{L}^{-1}\right)$} \\
\cline { 2 - 5 } & Reactive Turquoise Blue & $\begin{array}{c}\text { Reactive Yellow } \\
\text { G133 }\end{array}$ & Reactive Bordeaux & $\begin{array}{c}\text { Reactive Red } \\
\text { M8b }\end{array}$ \\
\hline 1 & 210.9143 & 127.6056 & 113.3125 & 140.7517 \\
2 & 421.8286 & 255.2112 & 226.625 & 281.5034 \\
3 & 632.7429 & 382.8168 & 339.9375 & 422.2551 \\
4 & 843.6572 & 510.4224 & 453.25 & 563.0068 \\
\hline
\end{tabular}



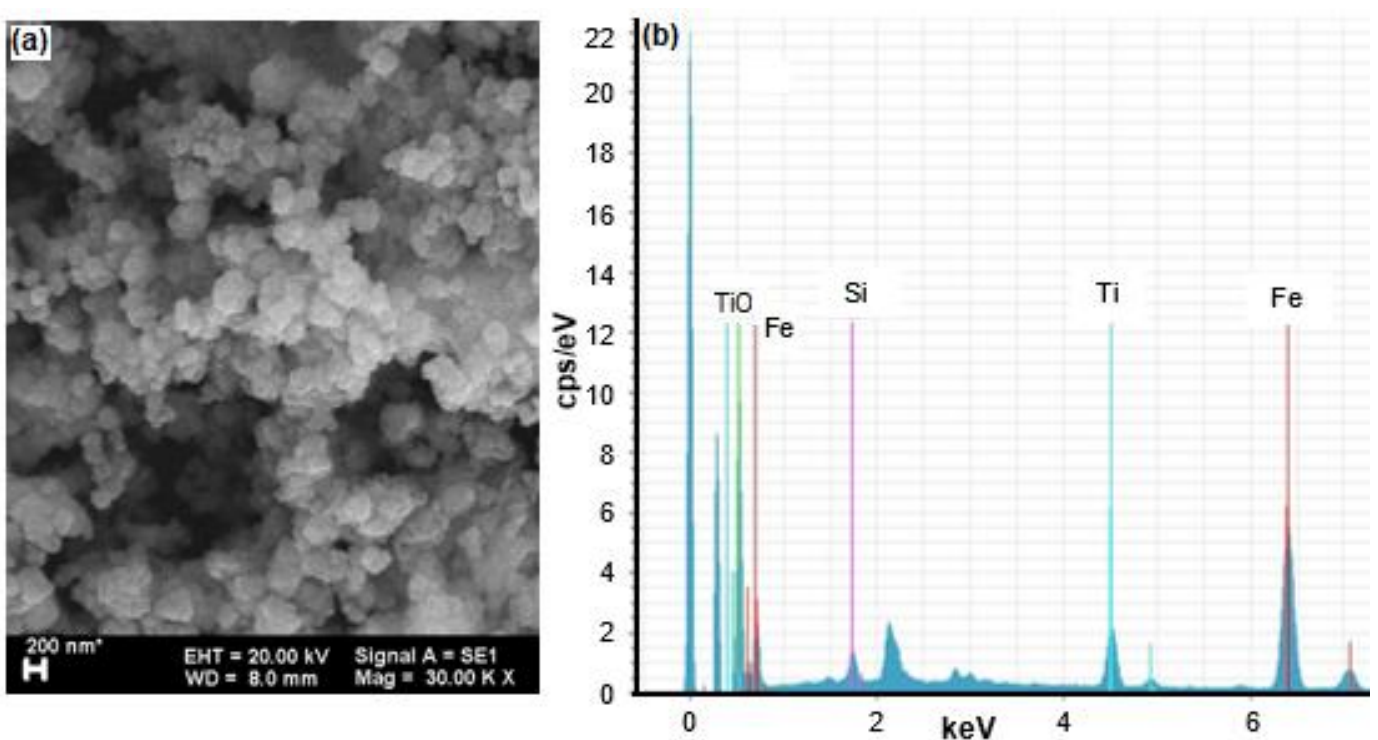

Fig 1. SEM images-EDS characteristic of $\mathrm{TiO}_{2}-\mathrm{Fe}_{3} \mathrm{O}_{4}$ photocatalyst. (a) SEM characteristic with the magnification of 30000x. (b) EDS spectrum

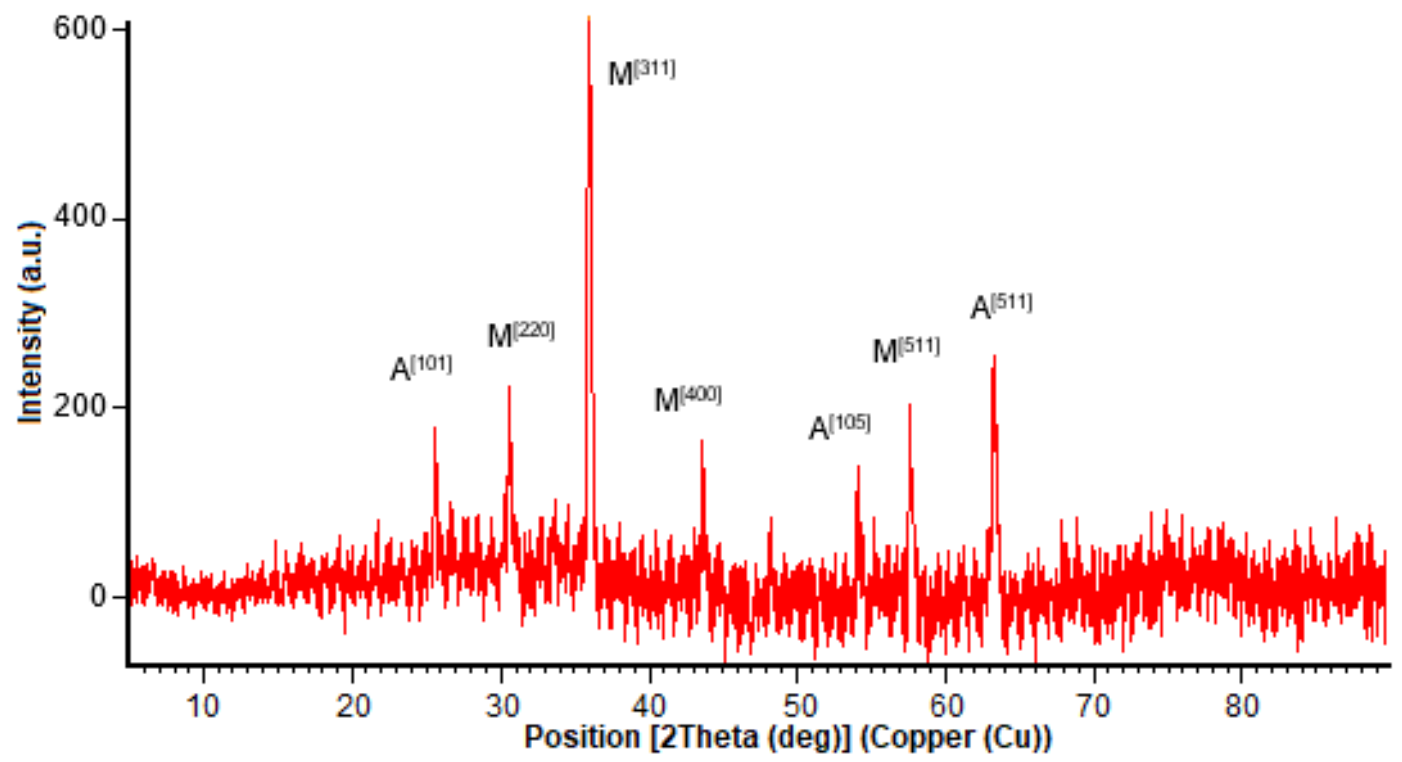

Fig 2. $\mathrm{XRD}$ pattern of $\mathrm{TiO}_{2}-\mathrm{Fe}_{3} \mathrm{O}_{4} . \mathrm{A}=$ anatase form of $\mathrm{TiO}_{2}, \mathrm{M}=$ magnetite $\left(\mathrm{Fe}_{3} \mathrm{O}_{4}\right)$

Table 5. Element composition of $\mathrm{TiO}_{2}-\mathrm{Fe}_{3} \mathrm{O}_{4}$ photocatalyst

\begin{tabular}{ccccc}
\hline No & Element & $\begin{array}{c}\text { Atomic } \\
\text { Number }\end{array}$ & $\begin{array}{c}\text { Atom. C } \\
\text { (at. \%) }\end{array}$ & Error (\%) \\
\hline 1 & $\mathrm{O}$ & 8 & 80.18 & 16.2 \\
2 & $\mathrm{Fe}$ & 26 & 16.03 & 0.7 \\
3 & $\mathrm{Ti}$ & 22 & 2.95 & 0.1 \\
4 & $\mathrm{Si}$ & 14 & 0.84 & 0.1 \\
\hline
\end{tabular}

spectrum pattern confirmed that there are small impurities of Si. Distribution of each atomic composition can be seen at Table 5. Oxygen, iron, and titanium remain the major component of the photocatalyst sample, which is an oxide substance of magnetite and titania.

The XRD pattern in Fig. 2 displayed the characteristic peak planes of anatase form of $\mathrm{TiO}_{2}$ [101] and magnetite [311], which are at $2 \theta=25.52^{\circ}$ and $2 \theta=$ $35.9305^{\circ}$ respectively (NBS Monograph 25 Section 5 and 7). The diffraction peak intensity was also higher in the magnetite peak, which was in agreement with the higher ratio of magnetite to titania in the making process of the photocatalyst. The anatase phase of $\mathrm{TiO}_{2}$ particle was reported to exert a higher photocatalytic activity than rutile [21. The d-spacing values of anatase $\mathrm{TiO}_{2}$ 
Table 6. Effect of binder variation on photocatalytic decolorization of four dye solutions after 3 hr solar irradiation

\begin{tabular}{llcccc}
\hline No & \multicolumn{1}{c}{ Treatment } & \multicolumn{3}{c}{ Color Removal Efficiency (\%) } \\
\cline { 3 - 6 } & & $\begin{array}{c}\text { Reactive Turquoise } \\
\text { Blue G 133 }\end{array}$ & $\begin{array}{c}\text { Reactive Yellow } \\
\text { M4g }\end{array}$ & $\begin{array}{c}\text { Reactive } \\
\text { Bordeaux B }\end{array}$ & $\begin{array}{c}\text { Reactive Red } \\
\text { M8b }\end{array}$ \\
\hline 1 & Negative Control & $7.112^{\mathrm{e}}$ & $15.784^{\mathrm{d}}$ & $12.893^{\mathrm{e}}$ & $19.232^{\mathrm{e}}$ \\
2 & Only Photocatalyst & $73.744^{\mathrm{b}}$ & $75.386^{\mathrm{b}}$ & $73.400^{\mathrm{b}}$ & $62.619^{\mathrm{b}}$ \\
3 & Only cement & $59.283^{\mathrm{cd}}$ & $50.828^{\mathrm{c}}$ & $28.254^{\mathrm{c}}$ & $51.203^{\mathrm{e}}$ \\
4 & Photocatalyst + acrylate glue & $49.97^{\mathrm{d}}$ & $44.647^{\mathrm{c}}$ & $28.254^{\mathrm{d}}$ & $45.57^{\mathrm{d}}$ \\
5 & Photocatalyst + White cement & $95.757^{\mathrm{a}}$ & $96.799^{\mathrm{a}}$ & $93.685^{\mathrm{a}}$ & $91.896^{\mathrm{a}}$ \\
6 & Photocatalyst + oil-based paint & $63.228^{\mathrm{c}}$ & $50.441^{\mathrm{c}}$ & $58.384^{\mathrm{c}}$ & $57.573^{\mathrm{bc}}$ \\
\hline
\end{tabular}

a Initial Concentration of Reactive Turquoise Blue $\mathrm{G} 133=210.9143 \mathrm{mg} \cdot \mathrm{L}^{-1}$; Reactive Yellow $4 \mathrm{G}=127.6056 \mathrm{mg} \cdot \mathrm{L}^{-1}$; Reactive Bordeaux B $=$ $113.3125 \mathrm{mg} \cdot \mathrm{L}^{-1}$; Reactive Red $8 \mathrm{~B}=140.7517 \mathrm{mg} \cdot \mathrm{L}^{-1}$

b Data are expressed as mean of duplicated experiments. Different letters represented significance difference within a column refer to Tukey's HSD test utilizing $\alpha=5 \%$ among various binders and control treatments

peak [101] and magnetite peak [311], also relatively matched with the standard, which the respective dspacing values are $3.48986 \AA$ and $2.49947 \AA$ (NBS Monograph 25 Section 5 and 7). Using the major peaks, which are in position $(2 \theta)$ of $25.5247,30.5371,35.9305$, $43.6549,54.0490,57.5890$, and $63.2068^{\circ}$, the average crystallite size was $68.85 \mathrm{~nm}$.

\section{Influence of Binder on Decolorization of Four Reactive Dyes}

The results of the photocatalytic decolorization of four reactive dyes are shown in Table 6 . After $3 \mathrm{~h}$ of solar irradiation, negative control without photocatalyst and binder exhibit significance different which were the lowest among other treatments. These results demonstrated that the dye cannot be simply degraded by solar light and temperature alone. The addition of mobile photocatalyst significantly enhanced the decolorization process, indicating that the presence of the photocatalyst was essential. Among three binders used in this study, white cement significantly showed the highest color removal efficiency. This result was in agreement with Khatee et al. [34]. Cement itself is composed of many minerals, such as silica, alumina, hematite, and even titania that can adsorb many substances [45-46]. Adsorption is an important process due to the nature of the degradation reaction. The radical formed on the irradiated photocatalyst surface attacks adsorbed organic molecules which is in proximity, producing the degradation and mineralization of the molecules [1]. It has been confirmed that there is a mutual effect between photocatalyst and cementitious matrix regarding to the degradation of $\mathrm{NO}_{x}$, which was done because of the adsorption properties of cement [47]. Some reports mentioned that wet mixing paint with photo- $\mathrm{TiO}_{2}$ (P25) reduce the photoactivity of the $\mathrm{TiO}_{2}$ due to the higher dispersion of photocatalyst on the paint matrix [48-49]. $\mathrm{CaCO}_{3}$ in the paint has been deduced to make interaction with the photocatalyst, hence prolonged the photoactivity to reach the steady-state. The organic compounds of paint (binder, dispersing agents, and other additives) were also responsible for covering the photoactivity [49]. The cyanoacrylate glue also hid the photocatalyst, thus reducing the degradation activity [50]. Nevertheless, it could be deduced that white cement is the best photocatalyst binder in this decolorization study.

\section{Decolorization Kinetics}

The reaction type of photocatalytic decolorization was done by hydroxyl radicals that attack the dye molecule over the photocatalyst surface $[41,43]$. It was well known that the light energy greater than $\mathrm{TiO}_{2}$ suspension band gap energy $(3.2 \mathrm{eV})$ can generate conduction band electrons $\left(\mathrm{e}_{\mathrm{CB}}{ }^{-}\right)$and valence band holes $\left(\mathrm{h}_{\mathrm{B}^{+}}\right)$are generated. The holes can react with water or hydroxyl anion $\left(\mathrm{OH}^{-}\right)$to produce hydroxyl radical $\mathrm{OH}^{\bullet}$ that is responsible to the decomposition of dye molecules [15]. The reaction can be written as followed [15]:

$$
\begin{aligned}
& \mathrm{TiO}_{2}+\mathrm{hv}(\mathrm{UV}) \rightarrow \mathrm{TiO}_{2}\left(\mathrm{e}_{\mathrm{CB}^{-}}+\mathrm{h}_{\mathrm{VB}^{+}}\right) \\
& \mathrm{TiO}_{2}\left(\mathrm{~h}_{\mathrm{VB}^{+}}\right)+\mathrm{H}_{2} \mathrm{O} \rightarrow \mathrm{TiO}_{2}+\mathrm{H}^{+}+\mathrm{OH}^{\bullet} \\
& \mathrm{TiO}_{2}\left(\mathrm{~h}_{\mathrm{VB}^{+}}\right)+\mathrm{OH}^{-} \rightarrow \mathrm{TiO}_{2}+\mathrm{OH}^{\bullet}
\end{aligned}
$$

Dye $+\mathrm{OH}^{\bullet} \rightarrow$ photodecomposition products

While Langmuir-Hinshelwood kinetics can be used to represent the reaction rate (eq. 3), the LangmuirHinshelwood equation can be well-fitted to the pseudofirst-order equation (eq. 4 and 5) in order to find the values of apparent first-order rate constant ( $\left.k^{\prime}\right)$ prior to determining the adsorption equilibrium constant $(\mathrm{K})$ and the surface reaction rate constant $(k)$ in the LangmuirHinshelwood model. A plot of $\ln \left(\mathrm{C} / \mathrm{C}_{0}\right)$ vs irradiation time is given on Fig. 3 to measure the $\mathrm{k}^{\prime}$ values, which has the same values as the slope in the linear regression plot. The values of slope ( $k^{\prime}$ values), intercept values, and $r^{2}$ are given in Table 7 for each dye and each concentration.

As shown in Table 7, there were good linear 

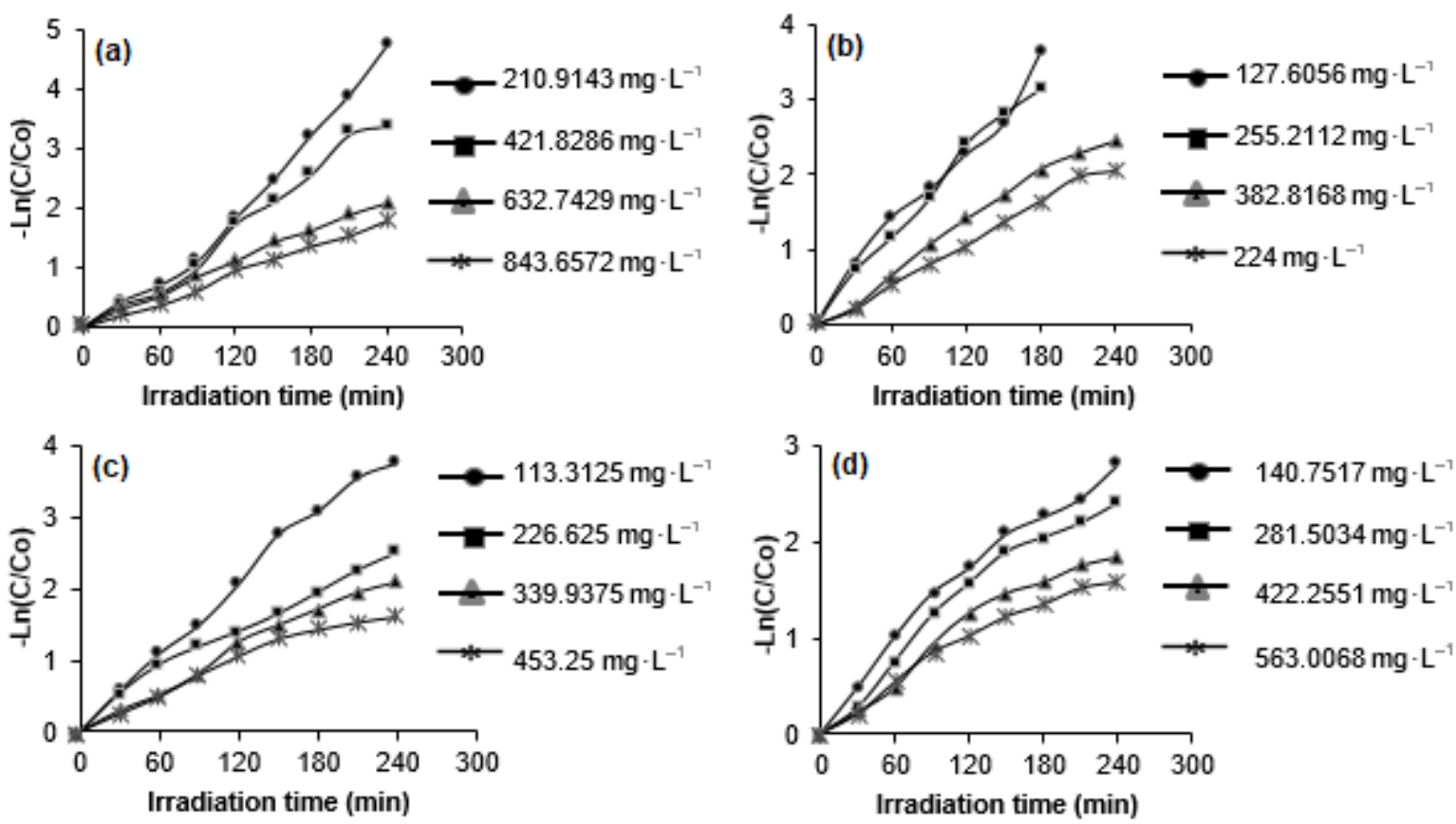

Fig 3. Photodegradation pseudo-first-order kinetics plot of solar photocatalytic based decolorization of four dyes solutions. (a) Reactive Turquoise Blue G. (b) Reactive Yellow M4g. (c) Reactive Bordeaux B. (d) Reactive Red M8b

Table 7. Pseudo-first-order rate constant values of four dyes solutions solar photocatalytic based decolorization in different concentration

\begin{tabular}{cccccc}
\hline No & Dye & $\begin{array}{c}\text { Concentration } \\
\left(\mathrm{mg} \cdot \mathrm{L}^{-1}\right)\end{array}$ & $\begin{array}{c}\text { Slopes }\left(\mathrm{k}^{\prime}\right) \\
\left(\mathrm{min}^{-1}\right)\end{array}$ & Intercept & $\mathrm{R}^{2}$ \\
\hline 1 & & 210.9143 & 0.0199 & -0.3467 & 0.9782 \\
2 & Reactive Turquoise & 421.8286 & 0.0152 & -0.1584 & 0.986 \\
3 & Blue G 133 & 632.7429 & 0.0088 & 0.0262 & 0.9969 \\
4 & & 843.6572 & 0.0075 & -0.0357 & 0.995 \\
\hline 5 & & 127.6056 & 0.0184 & 0.1417 & 0.9816 \\
6 & Reactive Yellow & 255.2112 & 0.0178 & 0.0959 & 0.9911 \\
7 & M4g & 382.8168 & 0.0108 & 0.0149 & 0.9887 \\
8 & & 510.4224 & 0.009 & -0.0271 & 0.9943 \\
\hline 9 & & 113.3125 & 0.0163 & 0.0946 & 0.9908 \\
10 & Reactive Bordeaux & 226.625 & 0.0098 & 0.2073 & 0.9846 \\
11 & B & 339.9375 & 0.0092 & 0.0301 & 0.9886 \\
12 & & 453.25 & 0.0071 & 0.0931 & 0.9677 \\
\hline 13 & & 140.7517 & 0.0112 & 0.2393 & 0.9706 \\
14 & Reactive Red M8b & 281.5034 & 0.0103 & 0.1325 & 0.9635 \\
15 & & 422.2551 & 0.0082 & 0.0768 & 0.9608 \\
16 & & 563.0068 & 0.0068 & 0.101 & 0.9683 \\
\hline
\end{tabular}

relationship in the pseudo-first-order reaction between $\ln \left(\mathrm{C} / \mathrm{C}_{0}\right)$ vs irradiation time according to the values of $\mathrm{r}^{2}$ (all above 0.96). According to the apparent reaction rate constant ( $\left.k^{\prime}\right)$ of each dye, there are tendencies of reduced rate constant that goes along with an increase of the dye concentration.

Langmuir-Hinshelwood model has been used by many authors to analyze the heterogeneous photocatalytic decolorization rate [38-40,44,51-52]. It is assumed that no intermediate products present or strongly absorbed than the dye on the surface of the photocatalyst $[38,40]$. Fig. 4 shows the plot of $1 / k^{\prime}$ vs initial concentration in order to determine the adsorption equilibrium constant $(\mathrm{K})$, reaction rate constant $(\mathrm{k})$, and the linearity in accordance to the values of $r^{2}$.

A good linearity is shown on the plot between $1 / k^{\prime}$ vs initial concentration of each dye $\left(r^{2}>0.9\right)$, means that the decolorization behavior fitted the LangmuirHinshelwood model [43]. By correlating the slope and intercept values in Table 8 to equation 6 , the $\mathrm{K}$ values of each dye, namely Reactive Turquoise Blue G 133, Reactive Yellow M4g, Reactive Bordeaux B and Reactive 

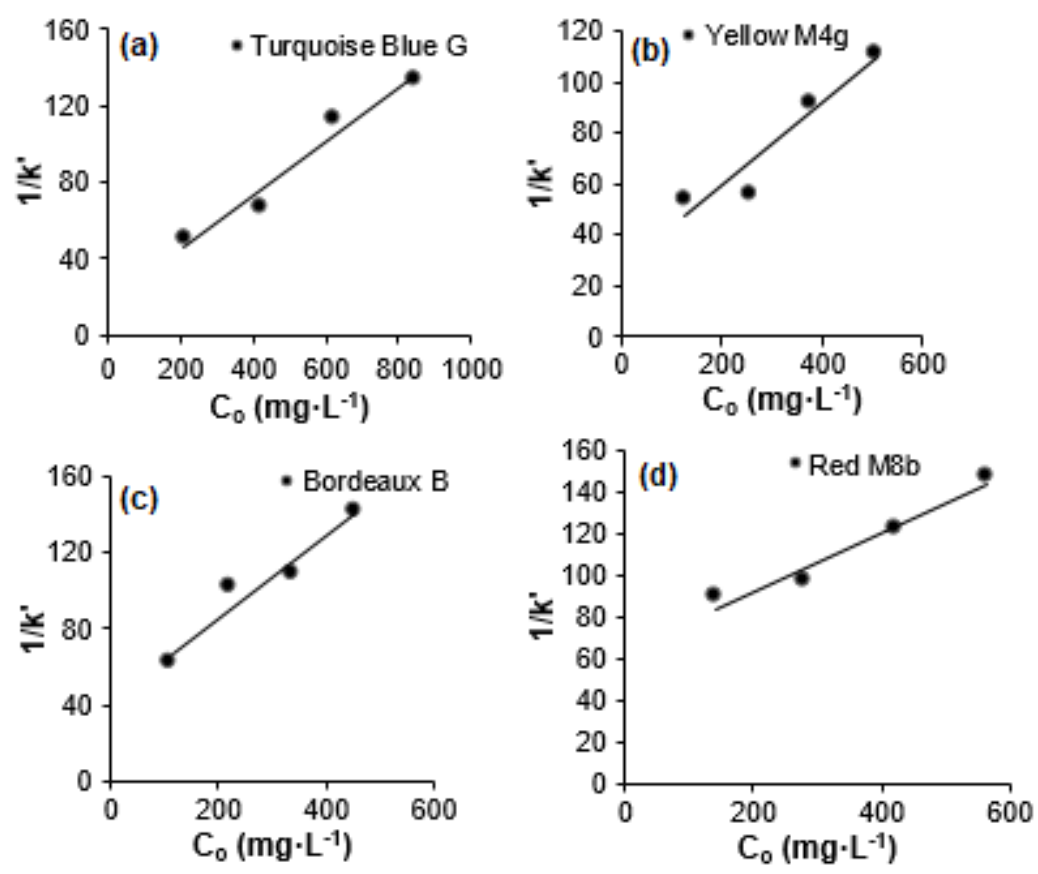

Fig 4. Langmuir-Hinshelwood model of dye decolorization. (a) Reactive Turquoise Blue G. (b) Reactive Yellow M4g. (c) Reactive Bordeaux B. (d) Reactive Red M8b

Table 8. The intercept, slope and $r^{2}$ values of the Langmuir-Hinshelwood model to the kinetics behavior of the four dyes decolorization

\begin{tabular}{cclll}
\hline No & \multicolumn{1}{c}{ Dye } & \multicolumn{1}{c}{ Slope } & \multicolumn{1}{c}{ Intercept } & \multicolumn{1}{c}{$\mathrm{R}^{2}$} \\
\hline 1 & Reactive Turquoise Blue G 133 & 0.1409 & 16.479 & 0.9593 \\
2 & Reactive Yellow M4g & 0.162 & 26.882 & 0.9115 \\
3 & Reactive Bordeaux B & 0.2163 & 41.938 & 0.9389 \\
4 & Reactive Red M8b & 0.1408 & 64.3 & 0.9566 \\
\hline
\end{tabular}

Red M8b are $0.0855,0.00603,0.00516$, and 0.00219 $\mathrm{L} \cdot \mathrm{mg}^{-1}$, respectively. While the values of reaction rate constant are 7.0972, 6.17284, 4.62321, and 7.10227 $\mathrm{mg} \cdot \mathrm{L}^{-1} \cdot \mathrm{min}^{-1}$ for each respective dye, which are Reactive Turquoise Blue G 133, Reactive Yellow M4g, Reactive Bordeaux B and Reactive Red M8b.

Combining the adsorption equilibrium constant and reaction rate constant, the Reactive Turquoise Blue G 133 is the fastest to be decolorized, while the slowest are between Reactive Bordeaux B and Reactive Red M8b because each respective dye has a slowest reaction rate constant and the smallest adsorption equilibrium constant. Reactive Bordeaux B contains two benzene rings, one triazine group, and one naphthalene rings, the most aromatic rings between all dyes. The aromatic ring is difficult to degrade and the naphthalene itself is more stable than benzene in the photodecoloration process $[12,53]$. It could be noticed that Reactive Turquoise Blue G 133 has the biggest value of adsorption equilibrium constant, indicating that the capacity of the photocatalyst to adsorb this compound is the highest. Reactive
Turqouise Blue G 133 also display a considerable high value of reaction rate constant compared to the other three dyes. Reactive Turquoise Blue G 133 is a highly ionic species due to the porphyrin ring that construct the dye [54]. It was shown that $\mathrm{TiO}_{2}$ adsorb and degrade better in the ionic environment of the substrate, as shown in the comparison of methyl orange versus methyl red $\mathrm{TiO}_{2}$-assisted photodecolorization [55]. It can be seen in Fig. 3 that the decrement of color concentration is better in the Reactive Yellow M4g than in the Reactive Red M8b. It can be accounted for the chemical structure of Reactive Red M8b contains two benzene rings and one naphthalene ring which is more difficult to degrade compared to the Reactive Yellow $\mathrm{M} 4 \mathrm{~g}$ that only contain three benzene rings and one pyrazole ring [12]. Some studies noted that the adsorption of dye is an important parameter besides the degradation reaction to determine the rate of decolorization and this phenomenon is also seen when comparing the adsorption rate constant of all four dyes in general $[13,15]$. 


\section{CONCLUSION}

Immobilization of $\mathrm{TiO}_{2}-\mathrm{Fe}_{3} \mathrm{O}_{4}$ photocatalyst in white cement binder showed the highest solar mediated decolorization efficiency in four dyes used in this study, namely Reactive Yellow M4g (Yellow 22), Reactive Red M8b (Red 11), Reactive Turquoise Blue G 133 (Blue 21), and Reactive Bordeaux B (Red 49), which ranged from $91-97 \%$. Moreover, the color removal of the cementimmobilized photocatalyst was higher than the mobile photocatalyst. The kinetic analysis fitted the LangmuirHinshelwood model and follow the pseudo-first-order reaction.

\section{ACKNOWLEDGEMENT}

We thank Mr. Marvel Lewi Santoso for providing us time to discuss the research.

\section{REFERENCES}

[1] Ajmal, A., Majeed, I., Malik, R.N., Idriss, H., and Nadeem, M.A., 2014, Principles and mechanisms of photocatalytic dye degradation on $\mathrm{TiO}_{2}$ based photocatalysts: A comparative overview, RSC Adv., 4 (70), 37003-37026.

[2] Kore, U.B., and Shukla, S.R., 2017, Ionic-liquidassisted mixed alkali system for reactive dye fixation in a batch process-optimisation through response surface methodology, Color. Technol., 133 (4), 325333.

[3] Tabassum, A., Bhatti, H.N., Nouren, S., and Zahid, M., 2015, Catalytic potential of gourd peel peroxidase for biodegradation of synthetic recalcitrant dyes fuchsin acid and crystal violet, J. Anim. Plant Sci., 25 (3), 777-783.

[4] Solano, A.M.S., Martínez-Huitle, C.A., GarciaSegura, S., El-Ghenymy, A., and Brillas, E., 2016, Application of electrochemical advanced oxidation processes with a boron-doped diamond anode to degrade acidic solutions of Reactive Blue 15 (Turquoise Blue) dye, Electrochim. Acta, 197, 210220.

[5] Khatri, A., Peerzada, M.H., Mohsin, M., and White, M., 2015, A review on developments in dyeing cotton fabrics with reactive dyes for reducing effluent pollution, J. Cleaner Prod., 87, 50-57.

[6] Saravanan, R., Karthikeyan, S., Gupta, V.K., Sekaran, G., Narayanan, V., and Stephen, A., 2013, Enhanced photocatalytic activity of $\mathrm{ZnO} / \mathrm{CuO}$ nanocomposite for the degradation of textile dye on visible light illumination, Mater. Sci. Eng., C, 33 (1), 91-98.

[7] Holkar, C.R., Jadhav, A.J., Pinjari, D.V., Mahamuni, N.M., and Pandit, A.B., 2016, A critical review on textile wastewater treatments: Possible approaches, J. Environ. Manage., 182, 351-366.

[8] Chung, K.T., 2016, Azo dyes and human health: A review, J. Environ. Sci. Health. Part C Environ. Carcinog. Ecotoxicol. Rev., 34 (4), 233-261.

[9] Chen, W., Xiao, H., Xu, H., Ding, T., and Gu, Y., 2015, Photodegradation of methylene blue by $\mathrm{TiO}_{2}-$ $\mathrm{Fe}_{3} \mathrm{O}_{4}$-bentonite magnetic nanocomposite, Int. $\mathrm{J}$. Photoenergy, 2015, 591428.

[10] Yanto, D.H.Y., Tachibana, S., and Itoh, K., 2014, Biodecolorization and biodegradation of textile dyes by the newly isolated saline-pH tolerant fungus Pestalotiopsis sp., J. Environ. Sci. Technol., 7 (1), 44-55.

[11] Gottlieb, A., Shaw, C., Smith, A., Wheatley, A., and Forsythe, S., 2003, The toxicity of textile reactive azo dyes after hydrolysis and decolourisation, $J$. Biotechnol., 101 (1), 49-56.

[12] Wang, Y.Z., 2000, Solar photocatalytic degradation of eight commercial dyes in $\mathrm{TiO}_{2}$ suspension, Water Res., 34 (3), 990-994.

[13] Aguedach, A., Brosillon, S., Morvan, J., and Lhadi, E.K., 2005, Photocatalytic degradation of azo-dyes reactive black 5 and reactive yellow 145 in water over a newly deposited titanium dioxide, Appl. Catal., B, 57 (1), 55-62.

[14] Jafari, H., and Afshar, S., 2016, Improved photodegradation of organic contaminants using nano- $-\mathrm{TiO}_{2}$ and $\mathrm{TiO}_{2}-\mathrm{SiO}_{2}$ deposited on Portland cement concrete blocks, Photochem. Photobiol., 92 (1), 87-101.

[15] Konstantinou, I.K., and Albanis, T.A., 2004, $\mathrm{TiO}_{2-}$ assisted photocatalytic degradation of azo dyes in aqueous solution: kinetic and mechanistic investigations: A review, Appl. Catal., B, 49 (1), 114.

[16] Kansal, S.K., Singh, M., and Sud, D., 2007, Studies on photodegradation of two commercial dyes in aqueous phase using different photocatalysts, J. Hazard. Mater., 141 (3), 581-590.

[17] Xavier, S., Gandhimathi, R., Nidheesh, P.V., and Ramesh, S.T., 2015, Comparison of homogeneous and heterogeneous Fenton processes for the removal of reactive dye Magenta MB from aqueous solution, Desalin. Water Treat., 53 (1), 109-118.

[18] Soon, A.N., and Hameed, B.H., 2011, Heterogeneous catalytic treatment of synthetic dyes in aqueous media using Fenton and photoassisted Fenton process, Desalination, 269 (1-3), $1-16$.

[19] Rossi, A.F., Amaral-Silva, N., Martins, R.C., and Quinta-Ferreira, R.M., 2012, Heterogeneous Fenton using ceria based catalysts: Effects of the calcination temperature in the process efficiency, Appl. Catal., B, 111-112, 254-263. 
[20] Zhang, J., Zhou, P., Liu, J., and Yu, J., 2014, New understanding of the difference of photocatalytic activity among anatase, rutile and brookite $\mathrm{TiO}_{2}$, Phys. Chem. Chem. Phys., 16 (38), 20382-20386.

[21] Syafei, D., Sugiarti, S., Darmawan, N., and Khotib, M, 2017, Synthesis and characterization of $\mathrm{TiO}_{2} /$ carbon nanoparticle (C-Dot) composites and their application as photocatalysts to degrade of persistent organic pollutant, Indones. J. Chem., 17 (1), 37-42.

[22] Cai, A., Guo, A., and Ma, Z., 2017, Immobilization of $\mathrm{TiO}_{2}$ nanoparticles on Chlorella pyrenoidosa cells for enhanced visible-light-driven photocatalysis, Materials, 10 (5), 541.

[23] Malato, S., Blanco, J., Vidal, A., and Richter, C., 2002, Photocatalysis with solar energy at a pilot-plant scale: An overview, App. Catal., B, 37 (1), 1-15.

[24] Bandala, E.R., and Estrada, C., 2007, Comparison of solar collection geometries for application to photocatalytic degradation of organic contaminants, J. Sol. Energy Eng., 129 (1), 22-26.

[25] Muruganandham, M., and Swaminathan, M., 2004, Solar photocatalytic degradation of a reactive azo dye in $\mathrm{TiO}_{2}$-suspension, Sol. Energy Mater. Sol. Cells, 81 (4), 439-457.

[26] Daghrir, R., Drogui, P., and Robert, D., 2013, Modified $\mathrm{TiO}_{2}$ for environmental photocatalytic applications: A review, Ind. Eng. Chem. Res., 52 (10), 3581-3599.

[27] Yang, S., Yang, L., Liu, X., Xie, J., Zhang, X., Yu, B., Wu, R., Li, H., Chen, L., and Liu, J, 2015, TiO 2 -doped $\mathrm{Fe}_{3} \mathrm{O}_{4}$ nanoparticles as high-performance Fentonlike catalyst for dye decoloration, Sci. China Technol. Sci., 58 (5), 858-863.

[28] Koesnarpadi, S., Santosa, S.J., Siswanta, D., and Rusdiarso, B, 2017, Humic acid coated $\mathrm{Fe}_{3} \mathrm{O}_{4}$ nanoparticle for phenol sorption, Indones. J. Chem., 17 (2), 274-283.

[29] El Ghandoor, H., Zidan, H.M., Khalil, M.M., and Ismail, M.I.M., 2012, Synthesis and some physical properties of magnetite $\left(\mathrm{Fe}_{3} \mathrm{O}_{4}\right)$ nanoparticles, Int. J. Electrochem. Sci., 7, 5734-5745.

[30] Neppolian, B., Kanel, S.R., Choi, H.C., Shankar, M.V., Arabindoo, B., and Murugesan, V., 2003, Photocatalytic degradation of reactive yellow 17 dye in aqueous solution in the presence of $\mathrm{TiO}_{2}$ with cement binder, Int. J. Photoenergy, 5 (2), 45-49.

[31] Matthews, R.W., 1991, Photooxidative degradation of coloured organics in water using supported catalysts $\mathrm{TiO}_{2}$ on sand, Water Res., 25 (10), 11691176.

[32] Määttä, J., Piispanen, M., Kymäläinen, H.R., UusiRauva, A., Hurme, K.R., Areva, S., Sjoberg, A.M., and Hupa, L., 2007, Effects of UV-radiation on the cleanability of titanium dioxide-coated glazed ceramic tiles, J. Eur. Ceram. Soc., 27 (16), 45694574.

[33] Gao, Y., and Liu, H., 2005, Preparation and catalytic property study of a novel kind of suspended photocatalyst of $\mathrm{TiO}_{2}$-activated carbon immobilized on silicone rubber film, Mater. Chem. Phys., 92 (2-3), 604-608.

[34] Khataee, A.R., Amani-Ghadim, A.R., Farajzade, M.R., and Ourang, O.V., 2011, Photocatalytic activity of nanostructured $\mathrm{TiO}_{2}$-modified white cement, J. Exp. Nanosci., 6 (2), 138-148.

[35] Agustina, T.E., Arsyad, F.S., and Abdullah M., 2013, Photocatalytic degradation of C.I. Reactive Red 2 using $\mathrm{TiO}_{2}$-coated PET plastic under solar irradiation, Adv. Mater. Res., 789, 180-188.

[36] Sahoo, C., Gupta, A.K., and Sasidharan-Pillai, I.M., 2012, Photocatalytic degradation of methylene blue dye from aqueous solution using silver ion-doped $\mathrm{TiO}_{2}$ and its application to the degradation of real textile wastewater, J. Environ. Sci. Health. Part A Toxic/Hazard. Subst. Environ. Eng., 47 (10), 14281438.

[37] Sun, Z., Chen, Y., Ke, Q., Yang, Y., and Yuan, J., 2002, Photocatalytic degradation of a cationic azo dye by $\mathrm{TiO}_{2} /$ bentonite nanocomposite, $J$. Photochem. Photobiol., A, 149 (1-3), 169-174.

[38] Muruganandham, M., and Swaminathan, M, 2006, Photocatalytic decolourisation and degradation of Reactive Orange 4 by $\mathrm{TiO}_{2}-\mathrm{UV}$ process, Dyes Pigm., 68 (2-3), 133-142.

[39] Kazeminezhad, I., and Sadollahkhani, A., 2014, Photocatalytic degradation of Eriochrome black-T dye using $\mathrm{ZnO}$ nanoparticles, Mater. Lett., 120, 267-270.

[40] Ollis, D., Silva, C.G., and Faria, J., 2015, Simultaneous photochemical and photocatalyzed liquid phase reactions: Dye decolorization kinetics, Catal. Today, 240, 80-85.

[41] Liang, X., Zhong, Y., Zhu, S., Ma, L., Yuan, P., Zhu, J., He, H., and Jiang, Z, 2012, The contribution of vanadium and titanium on improving methylene blue decolorization through heterogeneous UVFenton reaction catalyzed by their co-doped magnetite, J. Hazard. Mater., 199-200, 247-254.

[42] Rauf, M.A., Bukallah, S.B., Hamadi, A., Sulaiman, A., and Hammadi, F., 2007, The effect of operational parameters on the photoinduced decoloration of dyes using a hybrid catalyst $\mathrm{V}_{2} \mathrm{O}_{5} / \mathrm{TiO}_{2}$, Chem. Eng. J., 129 (1), 167-172.

[43] Hanifehpour, Y., Soltani, B., Amani-Ghadim, A.R., Hedayati, B., Khomami, B., and Joo, S.W., 2016, Praseodymium-doped ZnS nanomaterials: Hydrothermal synthesis and characterization with enhanced visible light photocatalytic activity, J. Ind. Eng. Chem., 34, 41-50. 
[44] Song, L., Zhang, S., Wu, X., and Wei, Q., 2012, Synthesis of porous and trigonal $\mathrm{TiO}_{2}$ nanoflake, its high activity for sonocatalytic degradation of rhodamine $\mathrm{B}$ and kinetic analysis, Ultrason. Sonochem., 19 (6), 1169-1173.

[45] Maruyama, I., Sakamoto, N., Matsui, K., and Igarashi, G., 2017, Microstructural changes in white Portland cement paste under the first drying process evaluated by WAXS, SAXS, and USAXS, Cem. Concr. Res., 91, 24-32.

[46] Zhang, Y.R., Kong, X.M., Lu, Z.B., Lu, Z.C., and Hou, S.S., 2015, Effects of the charge characteristics of polycarboxylate superplasticizers on the adsorption and the retardation in cement pastes, Cem. Concr. Res., 67, 184-196.

[47] Cárdenas, C., Tobón, J.I., García, C., and Vila, J., 2012, Functionalized building materials: Photocatalytic abatement of NOx by cement pastes blended with $\mathrm{TiO}_{2}$ nanoparticles, Constr. Build. Mater., 36, 820-825.

[48] Águia, C., Ângelo, J., Madeira, L.M., and Mendes, A., 2011, Photo-oxidation of NO using an exterior paintscreening of various commercial titania in powder pressed and paint films, J. Environ. Manage., 92 (7), 1724-1732.

[49] Águia, C., Ângelo, J., Madeira, L.M., and Mendes, A., 2011, Influence of paint components on photoactivity of P25 titania toward NO abatement, Polym. Degrad. Stab., 96 (5), 898-906.
[50] Matsumura, H., and Nakabayashi, N., 1988, Adhesive 4-META/MMA-TBB opaque resin with poly (methyl methacrylate)-coated titanium dioxide, J. Dent. Res., 67 (1), 29-32.

[51] Neppolian, B., Choi, H.C., Sakthivel, S., Arabindoo, B., and Murugesan, V., 2002, Solar/UV-induced photocatalytic degradation of three commercial textile dyes, J. Hazard. Mater., 89 (2-3), 303-317.

[52] Sahoo, C., and Gupta, A.K., 2015, Photocatalytic degradation of methyl blue by silver ion-doped titania: Identification of degradation products by GC-MS and IC analysis, J. Environ. Sci. Health. Part A Toxic/Hazard. Subst. Environ. Eng., 50 (13), 1333-1341.

[53] Kang, M.G., Park, H.S., and Kim, K.J., 2002, Effect of improved crystallinity of titanium silicalite-2 on photodecomposition of simple aromatic hydrocarbons, J. Photochem. Photobiol., A, 149 (13), 175-181.

[54] Marchis, T., Avetta, P., Bianco-Prevot, A., Fabbri, D., Viscardi, G., and Laurenti, E., 2011, Oxidative degradation of Remazol Turquoise Blue G 133 by soybean peroxidase, J. Inorg. Biochem., 105 (2), 321-327.

[55] Petrella, A., Boghetich, G., Petrella, M., Mastrorilli, P., Petruzzelli, V., and Petruzzelli, D., 2014, Photocatalytic degradation of azo dyes. Pilot plant investigation, Ind. Eng. Chem. Res., 53 (7), 25662571 . 